\title{
THE CONTRIBUTION OF DOUBLE-FED WIND FARMS TO TRANSIENT VOLTAGE AND DAMPING OF POWER GRIDS
}

\author{
Zhenghang Hao, Zhiqing Yao, Shaohua Li, Ailing Zhang, Zhuo Chen, Jianyun Chai
}

Original scientific paper

To improve the ability of transient voltage support and that of damping system oscillation, this paper presents the additional transient control scheme of wind farm. The analysis indicates that under the condition of strong grids, relying on wind turbines' own reactive power to support the transient voltage drop leads to the significant increase of rotor current; under the condition of weak grids, transient reactive power released by wind farms not only serves to suppress transient voltage drop but also makes acceptable the increase of rotor excitation current. In addition, when double-fed induction generators are mixed with conventional power plants for power transmission, we can control the increase of system damping by adding damping through wind turbines in a bid to improve the stability of the overall system. In order to implement this scheme, we produce the experimental prototype composed of IPC, fieldbus and optical equipment and conduct the closed-loop test on the real-time digital simulator (RTDS). Simulations show that under the condition of weak grids, implementing the reactive power regulation of wind farms can suppress their voltage drop to a certain extent.

Keywords: additional voltage control; doubly-fed wind farms; power system; RTDS test; simulation

Doprinos dvostruko-napajanih vjetroelektrana prolaznom naponu i prigušenju energetskih mreža

Izvorni znanstveni članak

Kako bi se povećala mogućnost održavanja prolaznog napona i oscilacija sustava prigušenja, u radu se predstavlja dodatna prolazna upravljačka shema vjetroelektrane. Analiza pokazuje da u uvjetima jakih mreža, oslanjanje na vlastitu reaktivnu snagu turbina na vjetar u svrhu podrške pada prolaznog napona, dovodi do značajnog povećanja struje rotora; u uvjetima slabih mreža, prolazna reaktivna snaga vjetroelektrana ne samo da služi za prigušivanje pada prolaznog napona nego i čini prihvatljivom povećanje uzbudne struje rotora. Uz to, kad se dvostruko napajani indukcioni generatori pomiješaju s konvencionalnim energanama za prijenos snage, moguće je upravljati povećanjem prigušenja sustava dodajući prigušenje preko vjetroelektrana $u$ nastojanju poboljšanja stabilnosti cjelokupnog sustava. U svrhu implementacije ove sheme, proizvodimo eksperimentalni prototip sastavljen od IPC, glavne sabirnice i optičke opreme i provodimo ispitivanje zatvorene petlje na digitalnom simulatoru u realnom vremenu (RTDS). Simulacije pokazuju da u uvjetima slabih mreža implementacija regulacije reaktivne snage vjetreoelektrana može donekle prigušiti pad napona.

Ključneriječi: dodatna kontrola prolaznog napona; dvosturko-napajane vjetroelektrane; energetski sustav; RTDS test; simulacija

\section{Introduction}

The employing of the AC-drive excitation and vector control technology by DFIG-based wind turbines makes such power generation technology more advantageous and therefore widely used $[1 \div 4]$. The advantages of DFIG include: its rotor speed can vary according to the wind speed to obtain the maximum wind; its power factor can reach 1; it causes smaller voltage fluctuation; its active and reactive power can be under decoupling control. Therefore, DFIG have obvious advantages over cage asynchronous motors in wind power generation projects. However, with the rapid growth of single DFIG capacity and wind farm installed capacity, grid-connected DFIGs gradually manifest their deficiencies. Under the large disturbance of power grids, the anti-disturbance interference ability of DFIG lags far behind not only that of conventional synchronous motors (SG) but also that of permanent magnet direct drive wind turbines [5]. In actual operation, we can find that even Grid faults away from the wind farm can also result in the severe voltage drop of wind farms [6]. Therefore, analysing the dynamic behaviour of DFIG and improving the fault ride-through capability is a thorny issue which has been attracting widespread attention.

Under the grid disturbance, dynamic behaviours of DFIG are generally manifested as the dip of its stator voltage and the surging of its rotor current. To protect the excitation frequency converter, the sustained growth of too large rotor currents is not allowed. Thus, the cause analysis and prevention measure of rotor over-current have always been the focus of researchers $[7 \div 16]$. Literature $[7 \div 10]$ holds that during grid faults, the DC component and negative sequence component of DFIG stator flux linkage generate a large induced electromotive force on the rotor side which can cause rotor over-current. On the basis of such understanding, it becomes a commonly used measure to offset the transient component of stator flux linkage so as to inhibit the rotor over-current by way of rotor current control [7,9]. What's more, schemes such as the nonlinear control strategy [11], additional damping control [12], additional voltage regulation [13], feed-forward compensation [14] and improvement of rotor circuit topology [15] can also receive a certain effect. Furthermore, with regard to the prevention of rotor over-current, designing various crowbars to protect the circuit for the purpose of protecting the inverter is also a frequently used technical measure [16].

The above literature research focuses on the control and protection technology of single wind turbine, which can be categorized into the passive solutions. There is other literature which puts forward alternative solutions. Literature [19] assumes that under great disturbance, DFIG causes the terminal voltage sag as a result of absorbing a large amount of reactive power. Thus, taking certain technical measures to make DFIG release reactive power under power grid disturbance could reduce the offgrid risk of wind farms. Literature [20] studies the transient voltage and reactive power regulation of single unit, conducts the principle research by simplifying the transient reactive power voltage control model into single 
model and verifies the feasibility of transient reactive power voltage control.

This paper attempts to put forth a proactive assisted solution which puts emphasis on improving wind farms' ability to resist disturbance of the grid through the coordination control between wind farms and the grid. Currently, the transient control technology of wind farms is at a low level in that when grids get disturbed or have short circuit faults, wind farms can hardly provide reactive power support in a short time and they lack transient voltage control capability. The absence of transient reactive power and voltage control ability of large-scale double-fed wind farms brings greater risks to grid operation and is unfavourable to the safe operation of the wind farm itself at the same time. In reality, wind power grid-connection regulations from home and abroad all require that during the period of power grid fault and voltage fault, wind turbine generators should provide dynamic reactive power to support the grid voltage [17, 18]. There are still many practical problems to be solved to equip double-fed induction generators (group) with transient voltage support capabilities.

Previous studies have confirmed the possibility of adjusting transient reactive power and active power of wind turbine groups. But to implement this idea, the following questions need to be studied: ? what range is the time constant of reactive power and active power produced by wind turbine groups and whether the time constant can meet the required rapidity of supporting the grid in the transient process; ? whether the rotor current is overloaded and the price that wind turbines have paid is bearable when wind power group support the grid transient voltage; ? as hundreds of wind turbines are scattered in a dozen kilometres of vast areas and the control object space is dispersed, how to ensure real-time communication required by closed-loop control under the transient time scale. This paper preliminarily answers the above questions through theoretical analysis and prototype testing.

The framework of this paper is as follows: section two establishes the mathematical model of double-fed generators and provides the control model of machineside converters and grid-side converters; section three confirms that wind farms are equipped with transient voltage adjustment ability by analysing the response rapidity of DFIG reactive power. When wind farms are connected with strong grids and weak grids respectively, the increase of reactive power output by wind turbine generators will result in varying degrees of influence on converters, which will be analysed in detail in section four; meanwhile, considering the low frequency oscillation problem of the power system including wind farms, section five puts forward the strategy of additional damping control to implement the dynamic regulation of transient active power so as to achieve the purpose of suppressing low-frequency oscillation; section six conducts an analysis on the time delay problem of distributed communication; section seven and section eight carry out the emulation study and prototype testing respectively to verify the correctness of this paper's theoretical analysis; the last part deals with the summary of this paper.

\section{The mathematical model of doubly-fed wind generators}

As shown in Fig. 1, the basic physical structure of doubly-fed wind generators consists of the wind turbine, shaft and gear box, double-fed induction generator, dual PWM converter and its control system [1, 2].

Wind turbines function by converting the wind power obtained through vanes into the mechanical torque acting on the hub; the drive shaft and gear box are to transmit the driving function of wind turbines to power generators and improve the rotation speed. The gearbox gear ratio can reach as high as 100. Similar to winding asynchronous motors, double-fed induction generators transform the mechanical energy into electrical energy and guarantee the output of AC voltage with constant frequency; composed of two back-to-back voltage source converters (VSC), the dual PWM converter relies on the common $\mathrm{DC}$ capacitor to maintain the DC voltage. On the one hand, the dual PWM converter provides AC excitation voltage for double-fed motors. On the other hand, it provides the power flow path for rotors to rotate between grids and it can operate in four quadrants.

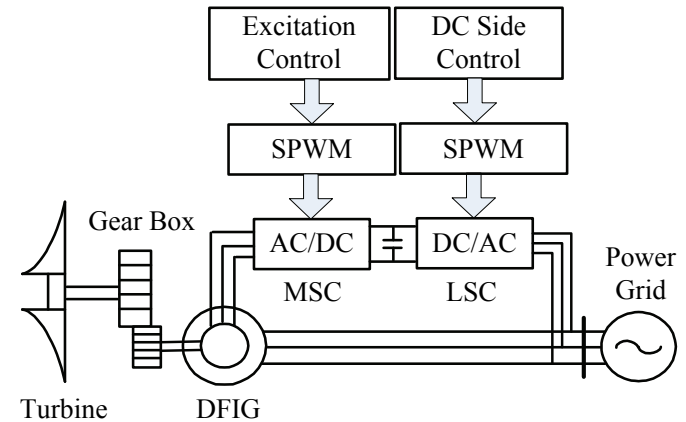

Figure 1 The block diagram of double-fed wind turbine generators

The core control unit of DFIG is the dual PWM converter including the machine-side converter and the grid-side converter. The one directly connected with rotor windings is called the machine-side converter which becomes the grid-side converter by being directly connected with the grid through linking with rotor circuit via the slip ring. The direct-current of two converters obtains direct-current support through the common capacitor. The basic function of the machine-side converter is to provide excitation voltage for double-fed generators and implement decoupling adjustment of active power and reactive power under the strategy of vector control; the major function of the grid-side converter is to maintain capacitor voltage constant under the control of direct-current regulation system and regulate the power factor. Furthermore, these two "backto-back" converters constitute the four-quadrant invertible flow system. In other words, active and reactive power flow in both directions can be achieved from the machine side to the grid side. Rotor-side converters produce the three-phase low-frequency AC current at the rotor circuit. The three-phase low-frequency AC current builds a lowfrequency rotating magnetic field relative to rotors and the rotational speed of the magnetic field can be regulated through dynamic control of the rotor converter. Compared with conventional synchronous generators (the magnetic pole is stationary relative to rotors), double-fed wind 
generators can operate in a large speed range, which is therefore called variable speed wind generators.

\subsection{The mathematical model of double-fed wind generators}

According to the generalized Park equation [20] of double-fed induction generators (DFIG), with the stator flux $\left(\psi_{d \mathrm{~s}}, \psi_{q \mathrm{~s}}\right)$ and the rotor current $\left(i_{d \mathrm{~s}}, i_{q \mathrm{r}}\right)$ being state variables, the state equation under the $d q$ coordinate system is expressed as:

$$
\left\{\begin{array}{l}
p \psi_{d \mathrm{~s}}=-\frac{r_{s}}{l_{s}} \psi_{d \mathrm{~s}}+l^{\prime \prime} r_{\mathrm{s}} i_{d \mathrm{r}}+\omega_{1} \psi_{q \mathrm{~s}} \\
p \psi_{q \mathrm{~s}}=-\frac{r_{\mathrm{s}}}{l_{\mathrm{s}}} \psi_{q \mathrm{~s}}+l^{\prime \prime} r_{\mathrm{s}} i_{q \mathrm{r}}-\omega_{1} \psi_{d \mathrm{~s}}+u_{q \mathrm{~s}} \\
p l^{\prime} i_{d \mathrm{r}}=-r_{\mathrm{r}} i_{d \mathrm{r}}+u_{d \mathrm{r}}+\omega_{\mathrm{s}} l^{\prime} i_{q \mathrm{r}}+\omega_{\mathrm{s}} l^{\prime \prime} \psi_{q \mathrm{~s}}-l^{\prime \prime} p \psi_{d \mathrm{~s}} \\
p l^{\prime} i_{q \mathrm{r}}=-r_{\mathrm{r}} i_{q \mathrm{r}}+u_{q \mathrm{r}}-\omega_{\mathrm{s}} l^{\prime} i_{d \mathrm{r}}-\omega_{\mathrm{s}} l^{\prime \prime} \psi_{d \mathrm{~s}}-l^{\prime \prime} p \psi_{q \mathrm{~s}}
\end{array} .\right.
$$

In this equation, $l^{\prime}=l_{\mathrm{r}}-\left(l_{\mathrm{m}}^{2} / l_{s}\right), l^{\prime \prime}=l_{\mathrm{m}} / l_{\mathrm{s}}, l_{\mathrm{s}}, l_{\mathrm{r}}$ and $l_{\mathrm{m}}$ represent the stator self-inductance, rotor selfinductance and mutual inductance respectively; $r_{\mathrm{s}}$ and $r_{\mathrm{r}}$ stand for the stator resistance and rotor resistance; $\omega_{1}$ and $\omega_{\mathrm{s}}$ are synchronous speed and slip; $u_{d \mathrm{r}}$ and $u_{q \mathrm{r}}$ are the vertical and horizontal component of the excitation voltage; $u_{q \mathrm{~s}}$ is the stator voltage; $p$ is the differential operator.

\subsection{The control model of machine-side converters}

Rotor windings of DFIG are connected with the PWM converter which outputs the AC voltage of dynamically adjustable frequency and amplitude under the vector control. Excitation regulation employs the double-closed-loop control structure with the outer one being the power control loop and the inner one the current control loop. The control block diagram is shown in Fig. 2 [2]. $P_{\mathrm{s}}$ and $p_{\text {ref }}$ stand for the stator active power and its reference value; $Q_{\mathrm{s}}$ and $q_{\text {ref }}$ represent the stator reactive power and its reference value; through the $d q / a b c$ transformation, $u_{d \mathrm{r}}$ and $u_{q \mathrm{r}}$ form the control signal under the $a b c$ coordinate and control the output voltage of the machine-side converter to achieve the decoupling control of the stator active power and reactive power.

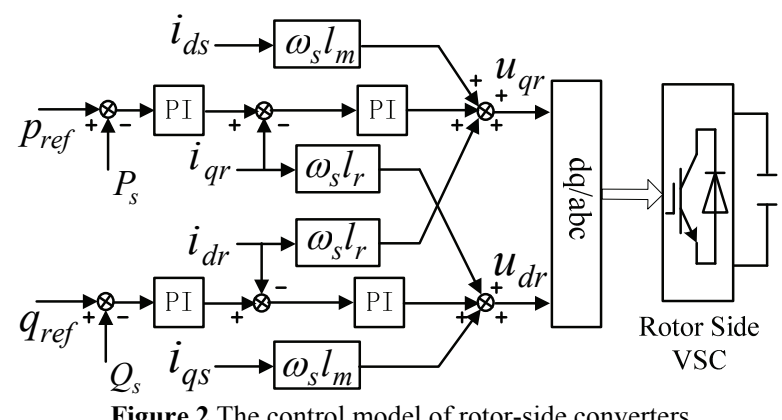

With regard to the $d q / a b c$ coordinate transformation, the $q$-axis of the $d q$ coordinate system can be taken as the stator voltage vector or stator flux vector or other vectors. When the stator flux vector is taken as the $q$-axis, we need to determine the direction of the stator flux that is obtained according to certain algorithms by measuring the stator current and rotor current. Double-fed generators use different control strategies at low wind speed and high wind speed. But we merely discuss the given control mode under high wind speed in that the reference value under low wind speed is not fixed.

\subsection{The control model of grid-side converters}

Similar to rotor-side converters, grid-side converters also achieve the active and reactive power decoupling control through the vector control strategy. Active power regulation can attain the goal of stabilizing DC-side capacitor voltage and in the meanwhile ensure that the slip power which can flow in a two-way fashion is transported to the grid via the DC-side converter and gridside converter; reactive power regulation can provide necessary support to the grid reactive power. Such function is similar to STATCOM. The control structure of grid-side converters is shown in Fig. 3. In Fig. 3, $v_{d c r e f}$ and $q_{\text {gref }}$ are the reference values of DC-side voltage and generator reactive power respectively; $v_{d \mathrm{c}}$ and $q_{\mathrm{g}}$ are the DC-side voltage and generator reactive power respectively; $i_{d \mathrm{~g}}$ and $i_{q \mathrm{~g}}$ represent the $d$-axis component and the $q$-axis component of the grid-side converter current respectively; $u_{\mathrm{s} q}$ is the grid-side voltage; $l$ is the choke inductor; $u_{d \mathrm{~g}}$ and $u_{q \mathrm{~g}}$ stand for the $d$-axis component and the $q$-axis component of the grid-side converter voltage; $\omega_{1}$ is the grid-side frequency. Through the $d q / a b c$ transformation, $u_{d \mathrm{~g}}$ and $u_{q \mathrm{~g}}$ form the control signal under the abc coordinate and control the output voltage of the grid-side converter to achieve the regulation of capacitor voltage and power factor.

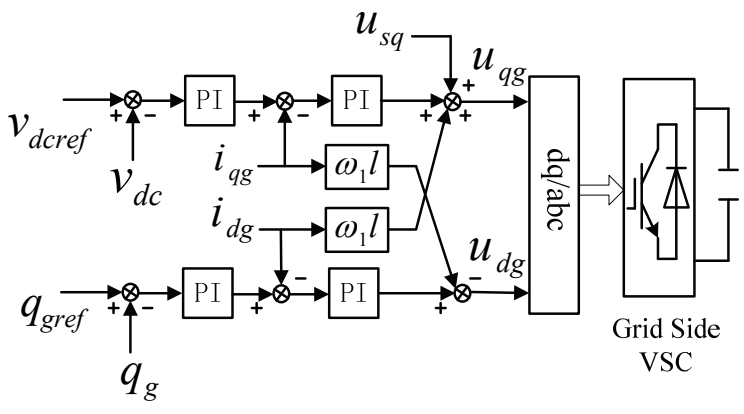

Figure 3 The control model of grid-side converters

\section{The rapidity analysis of DFIG power regulation}

Whether double-fed wind farms can send reactive power rapidly determines whether they possess the ability to regulate transient voltage. Therefore, it is necessary to analyse the rapidity of DFIG reactive power response.

Suppose:

$u_{d \mathrm{r}}^{*}=u_{d \mathrm{r}}+\omega_{\mathrm{s}} l^{\prime} i_{q \mathrm{r}}+\omega_{\mathrm{s}} l^{\prime \prime} \psi_{q \mathrm{~s}}-l^{\prime \prime} p \psi_{d \mathrm{~s}}$,

$u_{q \mathrm{r}}^{*}=u_{q \mathrm{r}}-\omega_{\mathrm{s}} l^{\prime} i_{d \mathrm{r}}-\omega_{\mathrm{s}} l^{\prime \prime} \psi_{d \mathrm{~s}}-l^{\prime \prime} p \psi_{q \mathrm{~s}}$,

then the state equation of rotor current in Eq. (1) can be represented as: 
$\left\{\begin{array}{l}p l^{\prime} i_{d \mathrm{r}}=-r_{\mathrm{r}} i_{d \mathrm{r}}+u_{d \mathrm{r}}^{*} \\ p l^{\prime} i_{q \mathrm{r}}=-r_{\mathrm{r}} i_{q \mathrm{r}}+u_{q \mathrm{r}}^{*}\end{array}\right.$.

Suppose the stator voltage vector as the $q$-axis of directional coordinates and when the network electromagnetic transient is neglected, stator reactive power and active power of DFIG can be represented as:

$\left\{\begin{array}{l}Q_{\mathrm{s}}=\frac{3}{2} \cdot\left(\frac{u_{q \mathrm{~s}} l_{\mathrm{m}} i_{d \mathrm{r}}}{l_{\mathrm{s}}}-\frac{u_{q \mathrm{~s}}^{2}}{\omega_{1} l_{\mathrm{s}}}\right) \\ P_{\mathrm{s}}=\frac{3}{2} \cdot \frac{u_{q \mathrm{~s}} l_{\mathrm{m}} i_{q \mathrm{r}}}{l_{\mathrm{s}}}\end{array}\right.$

From Eq. (3), we can know that the reactive power $Q_{\mathrm{s}}$ of stator windings can be controlled by the rotor current $i_{d \mathrm{r}}$ which is controlled by the excitation voltage $u_{d \mathrm{r}}^{*}$ of the $d$-axis with the time constant being $\tau=l^{\prime} / r_{\mathrm{r}} \cdot \tau$ generally ranges from $8 \mathrm{~ms}$ to $15 \mathrm{~ms}$. Based on the above analysis, we can determine that the reactive power regulation of DFIG stator windings possess the rapidity of millisecond, almost equivalent to the rapid reactive power output characteristics of STATCOM. That hundreds of wind turbines of the whole wind farm are fast tuned to the reactive power under unified control instructions is equivalent to a large-capacity "virtual STATCOM" being connected to the common bus of wind farms. The role that the "virtual STATCOM" plays in regulating the transient voltage of the common bus of wind farms cannot be underestimated.

\section{The cost analysis of transient reactive power support}

To maintain the grid voltage stability, we can consider using the reactive power sent by DFIG to support the grid voltage during the grid voltage dip period. However, the cost of this approach is to require that DFIG can provide the needed rotor current. If supporting the grid voltage leads to rotor over-current and causes damage to the excitation frequency converter, the above idea is inappropriate to be implemented.

It is generally believed that increasing the reactive power comes at a cost of increasing the rotor current significantly and as a result requires large excitation inverter capacity. In reality, the perception on the access of weak grids to wind power is inaccurate and entails further discussion under different scenarios.

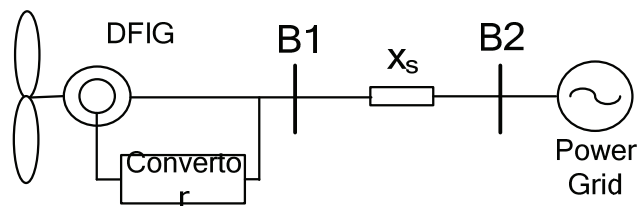

Figure 4 The diagram of the power system connected with the wind farm

To highlight the main issue, we make the wind farm equivalent to a wind turbine as shown in Fig. 4. B1 is the grid-connected point of the wind farm and B2 is the infinite bus. With $x_{\mathrm{s}}$ being the total reactance of transmission system (the venin reactance at B1), its size reflects the strength of the bus B1.

The so-called strong grid means that the system reactance $x_{\mathrm{s}}$ at bus $\mathrm{B} 1$ is very small or that $\mathrm{B} 1$ has a very large short-circuit capacity. For this scenario, $u_{q \mathrm{~s}}$, the voltage of $\mathrm{B} 1$ is almost free from the influence of the reactive power injected into B1. In the light of the Eq. (3), we can get:

$$
\left\{\begin{array}{l}
i_{d \mathrm{r}}=\frac{1}{l_{\mathrm{m}}}\left(\frac{2 Q_{\mathrm{s}} l_{\mathrm{s}}}{3 u_{q \mathrm{~s}}}+\frac{u_{q \mathrm{~s}}}{\omega_{1}}\right) \\
i_{q \mathrm{r}}=\frac{2 P_{\mathrm{s}} l_{\mathrm{s}}}{3 u_{q \mathrm{~s}} l_{\mathrm{m}}} \\
i_{\mathrm{r}}=\sqrt{i_{d \mathrm{r}}^{2}+i_{q \mathrm{r}}^{2}}
\end{array}\right.
$$

From Eq. (4), we can see that $i_{d \mathrm{r}}$ has a linear relationship with $Q_{\mathrm{s}}$. If $\mathrm{DFIG}$ increases the reactive power, the rotor current $i_{d \mathrm{r}}$ increases; as $u_{q \mathrm{~s}}$ remains basically unchanged, $i_{q \mathrm{r}}$ is proportional to $P_{\mathrm{s}}$. Then we arrive at the following conclusion: under certain $P_{\mathrm{s}}$, if the reactive power $Q_{\mathrm{s}}$ is expanded, $i_{d \mathrm{r}}$ increases linearly, $i_{q \mathrm{r}}$ stays unchanged and the full current $i_{\mathrm{r}}$ increases monotonically by non-linear law and vice versa.

The so-called weak grids refer to those in which $x_{\mathrm{s}}$ is relatively large or B1 has a small short-circuit capacity. For this scenario, $u_{q \mathrm{~s}}$, the voltage of $\mathrm{B} 1$, gets affected by the reactive power $Q_{\mathrm{s}}$ injected into B1. Relationship between the two can be approximately expressed as:

$u_{q \mathrm{~s}}=u_{q \mathrm{~s} 0}+\frac{Q_{\mathrm{s}} x_{\mathrm{s}}}{u_{q \mathrm{~s} 0}}$

$u_{q \mathrm{~s} 0}$ represents the terminal voltage before the reactive power is injected into B1. By substituting Eq. (5) in Eq. (4), we get:

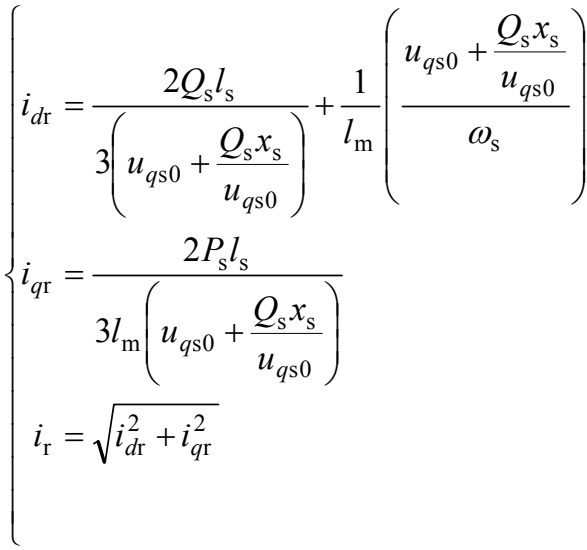

From Eq. (5) and Eq. (6), we can see that if $Q_{\mathrm{s}}$ is increased, $u_{q \mathrm{~s}}$ increases and meanwhile $i_{q \mathrm{r}}$ decreases. In other words, as far as weak grids are concerned, the injection of reactive current $i_{d \mathrm{r}}$ can enhance the bus voltage significantly so that active current $i_{q \mathrm{r}}$ can be reduced. As the excitation full current is composed of active component $i_{q \mathrm{r}}$ and reactive component $i_{d \mathrm{r}}$, the shifts 
between $i_{q \mathrm{r}}$ and $i_{d \mathrm{r}}$ make the variation law of the full current $i_{\mathrm{r}}$ more complex. According to the intensity of grid-connected points, the corresponding relationship between stator reactive power $Q_{\mathrm{s}}$ and rotor current $i_{\mathrm{r}}$ can be calculated through Eq. (6) as shown in Fig. 5.

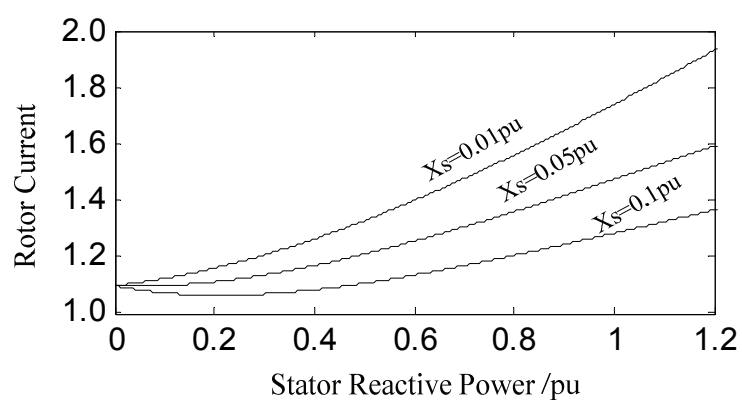

Figure 5 The relationship between the stator reactive power and the rotor current under weak grids

From Fig. 5, we can see that as far as weak grids $\left(x_{\mathrm{s}}\right.$ $=0,1 \mathrm{pu}$ ) are concerned, when DFIG's increased reactive power is not much, the rotor current decreases; when there is much increased reactive power, the rotor current is still in an upward trend with a small rate of rise. It is evident that there is little rotor inverter over-current risk caused by increased reactive power. However, as the grid becomes stronger $\left(x_{\mathrm{s}}=0,05 \mathrm{pu}\right.$ and $\left.x_{\mathrm{s}}=0,01 \mathrm{pu}\right)$, the increase of reactive power leads to the monotonic rise of rotor current with a large rate of rise and the increase of reactive power may increase the rotor inverter overcurrent risk significantly. In the light of the analysis of this section, we arrive at the conclusion that when weak grids are connected, it is necessary to regulate the gridconnected voltage relying on DFIGs' own reactive power.

\section{Simulation research}

As the control object, the wind farm is composed of 50 pieces of $1,5 \mathrm{MW}$ doubly-fed induction generators (DFIGs), which are connected altogether by long lines and big electric grids after they assemble in the $110 \mathrm{kV}$ transformer substation. Just as the attached Fig. 4 demonstrates, this example system adopts the MATLAB/Simulink modelling and forms a closed loop control system with the prototype.

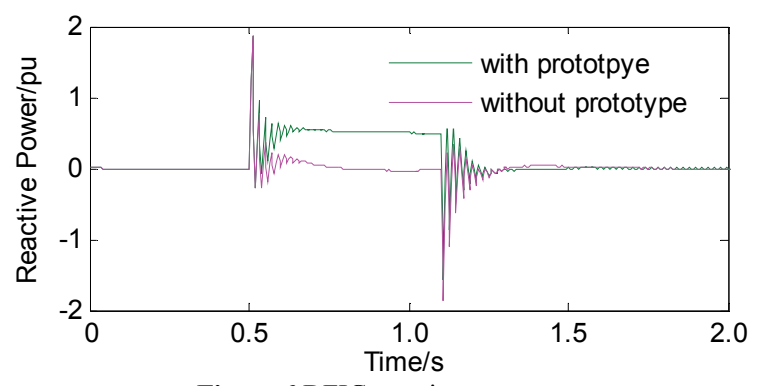

Figure 6 DFIG reactive response

Here is the transient test: a three-phase short circuit of the external grid of the wind farm occurs at $t=1,0 \mathrm{~s}$ (Fig. 4 ), and the failure caused bus B1 voltage to drop 0,28 pu. To test the control effect of the prototype, two conditions are compared and analysed, the first of which is prototype investment and the second is no investment of it. During the test, through the Simulink monitoring software, the reactive response of a wind turbine (similar to the rest fans) and the transient response of the wind farm bus voltage are measured, and results are shown in Figs. 6 and 8.

Fig. 6 explains the reactive response of the doublefed induction generator (DFIG). When the prototype is not invested, the reactive output of each DFIG declines slightly; when the prototype is invested, each DFIG can receive the reactive command from the remote controller in time and regulate reactive current quickly, and the reactive output increases. Two conclusions are drawn from this test: first, the rapid reactive response of DFIG, which is demonstrated in Section 3, is confirmed; second, it proves true that communication delay does not have significant influence on closed loop control.

Fig. 7 explains the transient voltage response of the wind farm bus B1. Because the reactive output of all fans grows when the grid failure takes place, B1 voltage drops more slightly: voltage drops to $0,72 \mathrm{pu}$ when the prototype is not invested; whereas voltage drops to 0,81 pu when the prototype is not invested. Therefore, it can be noted that the experimental prototype developed in this paper can make the wind farm support the bus voltage in the common connection point to some extent.

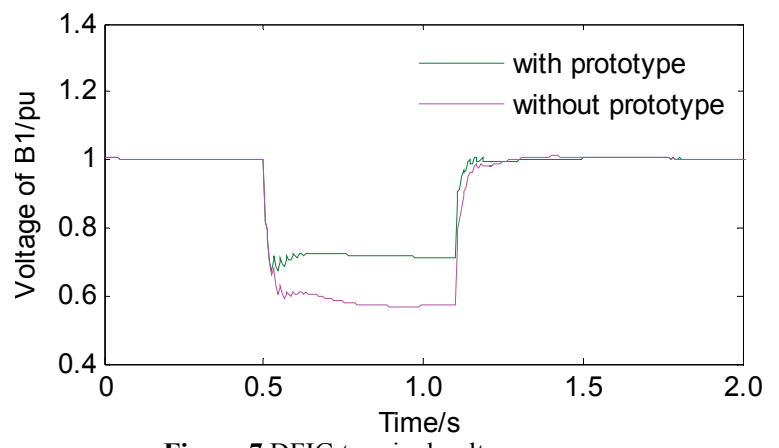

Figure 7 DFIG terminal voltage response

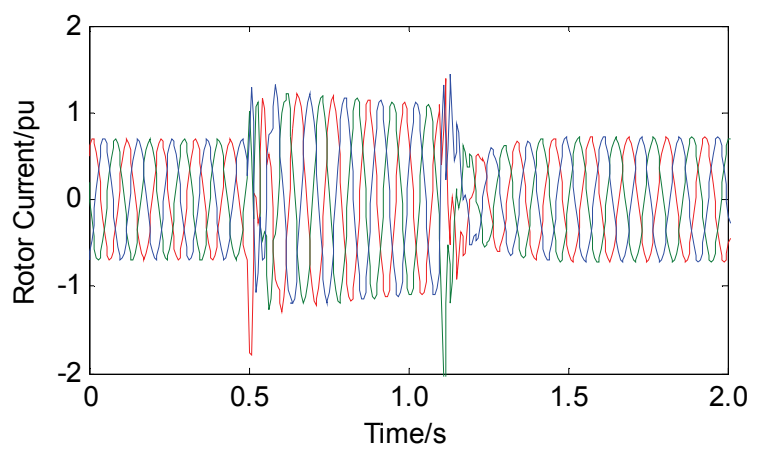

(a) with prototype

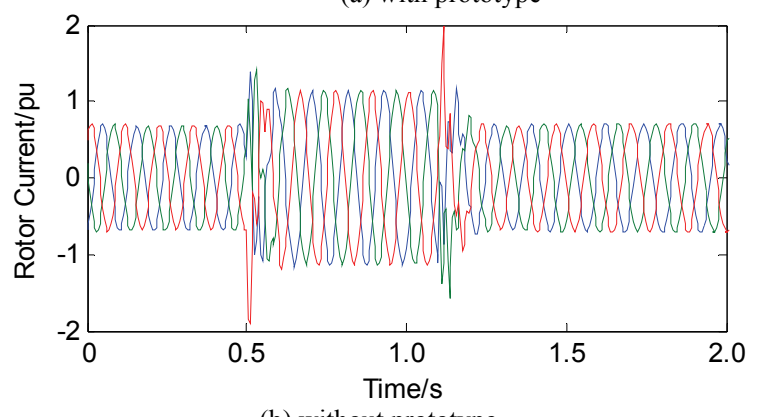

(b) without prototype

Figure 8 DFIG rotor current transient response 
Fig. 8 explains the transient response of DFIG rotor current. Grid failure leads to an increase of rotor current. There is little difference of the rotor current transient response when the prototype is invested or not. Experimental results correspond to the theoretical analysis circle in Fig. 5: under weak network conditions, the experimental prototype not only supports grid voltage but increases no additional burden to the fan rotor drive.

A conclusion can be drawn from the experiments above: when the system works in weak (negative) damping conditions, through regulating active output of each DFIG via the wind farm centralized platform and the wide area communications network, dynamic active output will have an additional damping control effect, which will consequently increase systematic damping and restrain low-frequency oscillations. In addition, this control method will have no negative effect on the fan or the system, and it is therefore a practical technical method.

\section{Conclusion}

Conclusions can be drawn as follows:

(1) Dynamically reactive and active response time constant of DFIG is very small, and it has reactive and active issuing capacity in a quick manner.

(2) When the wind farm is connected with a weak grid, it is necessary for the wind turbine group to regulate their own reactive power on the basis of grid conditions and demands, thus reducing the drop magnitude of the grid transient voltage.

(3) When the wind farm is in joint operation with the conventional plant, the wind farm can have a damping effect on the conventional power plant through the dynamic and active regulation and at the appropriate control strategy so as to prevent the conventional plant from low frequency oscillation.

(4) For the wind farm WAN fieldbus network, rapid communication can be guaranteed through the "broadcast" information transmission mode, and it can therefore be used as a high-speed closed-loop control communication method.

\section{Acknowledgments}

The authors gratefully acknowledge the support of the XJ Electric Co., Ltd Project, and the National Natural Science Fund of China (51267003) and Social Development Research Project of GuiZhou Province, China(SY[2011]3081).

\section{References}

[1] Pena, R.; Clare, J. C.; Asher, G. M. Doubly fed induction generator using back-to-back PWM converters and its application to variable-speed wind-energy generation. // IEE Proc., Electr. Power Appl. 143, 3(1996), pp. 231-241.

[2] Lie Xu. Direct active and reactive power control of DFIG for wind energy generation. // IEEE Transactions on Energy Conversion. 21, 3(2006), pp. 750-758.

[3] Fernández, L. M.; García, C. A.; Saenz, J. R. et al. Equivalent models of wind farms by using aggregated wind turbines and equivalent winds. // Energy Conversion and Management. 50, 2009, pp. 691-704.
[4] Datta, R.; Ranganathan, V. T. Variable-speed wind power generation using doubly fed wound rotor induction machine-A comparison with alternative schemes. // IEEE Trans on Energy Conversion. 17, 3(2002), pp. 414-421.

[5] Hansena, A. D.; Michalke, G. Fault ride-through capability of DFIG wind turbines. // Renewable Energy. 32, (2007), pp. 1594-1610.

[6] Morren, J.; Sjoerd, W. H. Ride-through of wind turbines with doubly-fed induction generator during a voltage dip. // IEEE Trans on Energy Conversion. 20, 2(2005), pp. 435441.

[7] Xiang, D. W.; Li, R. Control of a doubly fed induction generator in a wind turbine during grid fault ride-through. // IEEE Trans on Energy Conversion. 21, 3(2006), pp. 652662.

[8] Lopez, J.; Sanchis, P.; Roboam, X.; Marroyo, L. Dynamic behavior of the doubly fed induction generator during three-phase voltage dips. // IEEE Trans on Energy Conversion. 22, 3(2007), pp. 709-717.

[9] Lopez, J.; Gubía, E.; Olea, E.; Ruiz, J. Ride through of wind turbines with doubly fed induction generator under symmetrical voltage dips. // IEEE Trans on Industrial Electrinics. 56, 10(2009), pp. 4246-4253.

[10] Morren, J.; De Haan, S. W. H. Ride through of wind turbines with doubly-fed induction generator during a voltage dip. // IEEE Trans on Energy Conversion. 20, 2(2005), pp. 435-441.

[11] Rahimi, M.; Parniani, M. Grid-fault ride-through analysis and control of wind turbines with doubly fed induction generators. // Electric Power Systems Research, 80, (2010), pp. 184-195.

[12] Mishra, Y.; Mishra, S.;Tripathy, M. Improving Stability of a DFIG-Based Wind Power System With Tuned Damping Controller. // IEEE Trans on Energy Conversion. 24, 3(2009), pp. 650-659.

[13] Erlich, I.; Kretschmann, J.; Fortmann, J. Modeling of wind turbines based on doubly-fed induction generators for power system stability studies. // IEEE Trans on Power Systems. 22, 3(2007), pp. 909-919.

[14] Erlich, I.; Wrede, H.; Feltes, C. Dynamic Behavior of DFIG-Based Wind Turbines during Grid Faults. // IEEJ Transactions on Industry Applications. 128, 4(2008), pp. 909-919.

[15] Flannery, P. S.; Venkataramanan, G. A fault tolerant doubly fed induction generator wind turbine using a parallel grid side rectifier and series grid side converter. // IEEE Trans on Power Electronics. 23, 3(2008), pp. 1126-1135.

[16] El-Sattar, A. A.; Saad, N. H.; Shams El-Dein, M. Z. Dynamic response of doubly fed induction generator variable speed wind turbine under fault. // Electric Power Systems Research. 78, 2(2008), pp. 1240-1246.

[17] Ramtharan, G.; Ekanayake, J. B.; Jenkins, N. Frequency support from doubly fed induction generator wind turbines. // IET Renew. Power Gener. 1, 1(2007), pp.3-9.

[18] Mustafa, K.; Jovica, V.; Milanovic. Dynamic contribution of DFIG-based wind plants to system frequency disturbances. // IEEE Transactions on Power Systems. 24, 2(2009), pp. 859-867.

[19] Elkington, K.; Valerijs Knazkins, V.; Ghandhari, M. On the stability of power systems containing doubly fed induction generator-based generation. // Electric Power Systems Research. 78, (2008), pp. 1477-1484.

[20] El Moursi, M.; Joos, G.; Abbey, C. A secondary voltage control strategy for transmission level interconnection of wind generation. // IEEE Trans on Power Electronics. 23, 3(2008), pp. 1178-1190. 


\section{Authors' addresses}

Zhenghang Hao, Prof. Dr.

XJ Electric Co., Ltd

Guizhou University

School of electrical engineering

Guiyang, Guizhou Province, China

Zip code: 550003

E-mail: haozhenghang@163.com

\section{Zhiqing Yao, Prof. Dr.}

corresponding author

XJ Electric Co., Ltd

Xuchang City, Henan Province, China

Zip code: 461000

E-mail: zhiqingy@dlwg.net

Shaohua Li, Senior engineer

XJ Electric Co., Ltd

Xuchang City, Henan Province, China

Zip code: 461000

Ailing Zhang, Senior engineer

XJ Electric Co., Ltd

Xuchang City, Henan Province, China

Zip code: 461000

Zhuo Chen, Assist. Prof. Dr.

Guizhou University

School of electrical engineering

Guiyang, Guizhou Province, China

Zip code: 550003

E-mail: ee.chenz@gzu.edu.cn

Jianyun Chai, Prof. Dr.

Tsinghua University

State Key Lab of Power Systems,

Department of Electrical Engineering,

Beijing, China

Zip code: 100084 